\title{
EFFECT OF DRAGON FRUIT (HYLOCEREUS) CONSUMPTION ON CHOLESTEROL LEVEL IN WOMEN OF CHILDBEARING AGE, IN KEDIRI
}

\author{
Dina Dewi Anggraini \\ Diploma Program in Midwifery, Faculty of Health Sciences, Kadiri University
}

\begin{abstract}
Background: Hypercholesterolemia is widely recognized risk factors of heart disease. The dragon fruit (Hylrocereus), also known as Pitaya, has Vitamin A, between 1.30 to 1.08 Protid, Vitamin C 12-6, lipid, and glucide. It brings about a high level of nutritional value to human body. This study aimed to determine effect of dragon fruit (hylocereus) consumption on cholesterol level in women of childbearing age, in Kediri.

Subjects and Method: This was a quasi experimental study using before and after intervention with no control design. This study was conducted in Ngasem Health Center, Kediri, East Java. A sample of women of childbearing age who had cholesterol level $\geq 200 \mathrm{mg} / \mathrm{dL}$ and who did not consume anticholesterol agent, were selected for this study. The dependent variable was cholesterol level. The independent variable was consumption of the dragon fruit. Difference in mean cholesterol levels before and after intervention was tested by Wilcoxon test.
\end{abstract}

Results: Mean cholesterol level before consumption of dragon fruit (238.75 $\mathrm{mg} / \mathrm{dL}$ ) was reduced after consumption of dragon fruit $(187.92 \mathrm{mg} / \mathrm{dL})$, and it was statistically significant $(\mathrm{p}=0.002)$.

Conclusion: Dragon fruit is effective in reducing cholesterol level among women of childbearing age.

Keywords: dragon fruit, women of childbearing age, cholesterol level

Correspondence: Dina Dewi Anggraini. Diploma Program in Midwifery, Faculty of Health Sciences, Kadiri University. Email: dewidina9o@gmail.com. Mobile: +6282230057103 . 